\title{
Survey of Finance Companies, 1996
}

James D. August, Michael R. Grupe, Charles Luckett, and Samuel M. Slowinski, of the Board's Division of Research and Statistics, prepared this article. Wayne C. Cook, Pamela F. Gerbino, and Hank Leddon provided research assistance.

Finance companies are major suppliers of credit to businesses for motor vehicles and other equipment and to individuals for motor vehicles and other consumer goods and services. Finance companies also participate to a lesser extent in the provision of home equity loans and commercial mortgages. At year-end 1996, the value of assets owned or securitized by finance companies-total business and consumer loans and leases and real estate-related receivableswas slightly more than $\$ 800$ billion. In funding these receivables, finance companies have a sizable presence as borrowers in the markets for commercial paper and corporate bonds and as issuers of assetbacked securities.

Roughly 1,250 nondepository financial institutions make up the finance company sector. These institutions cover a broad range of types, from highly diversified providers of financial services to narrowly specialized firms and from multibillion-dollar organizations with nationwide operations to local smallloan companies with less than $\$ 10$ million in assets. Despite the diversity among firms, however, asset ownership is heavily concentrated: More than threefourths of the industry's receivables are owned or securitized by the 20 largest firms (see box "Industry Concentration," p. 548). ${ }^{1}$

The Federal Reserve System has been surveying the assets and liabilities of finance companies, typically at five-year intervals, since June 1955. The quinquennial survey is designed primarily to establish benchmark data for the System's monthly published series on the outstanding receivables of finance companies and to provide a comprehensive update on

1. Owned receivables are those assets that are held and financed directly on the balance sheet. Securitized receivables-also referred to within the finance company industry as "managed" receivables-are those assets that have been securitized with servicing rights retained, thereby generating fee income as off-balance-sheet items. the sources of funds for these companies. ${ }^{2}$ This article summarizes the results of the most recent survey, which covers balance sheet information as of June 30, 1996. ${ }^{3}$ Special features of the 1996 survey are a breakdown of automobile leases into consumer and business components and, relative to previous surveys, greater detail on the composition of real estate credit and more information on securitized loans and leases. ${ }^{4}$ (See appendix A for details of the survey's sampling procedures and for balance-sheet results by size of company.)

\section{RECEIVABLES REPORTED BY FINANCE COMPANIES}

Over the period bounded by the last two surveys (1990-96), the total value of receivables owned or securitized by finance companies increased more than 50 percent, to $\$ 771$ billion (table 1) (all survey data reported here are as of June 30 of the relevant year). Over that period, which encompassed an economic recession and subsequent recovery and expansion, industry receivables grew at a compound annual rate of 7.3 percent, about 3 percentage points faster than the growth of nominal GDP. Of special note in the 1996 survey data is the shift in the share of total receivables from business, which declined seven percentage points, to consumers, which rose six points. Even so, business receivables remained the largest component as of mid-1996. The share of receivables related to real estate in $1996,13.5$ percent, was roughly the same as it was in 1990.

Another important development during the period was the growth of securitization as an alternative to on-balance-sheet financing. Securitization involves pooling loans together, selling securities with the

2. Monthly data on finance company activities are collected on the Domestic Finance Company Report of Consolidated Assets and Liabilities (FR 2248; OMB No. 7100-0005) and published in the G.20 Federal Reserve Statistical Release, "Receivables Outstanding at Finance Companies."

3. The survey was originally scheduled for June 1995, but delays in implementation caused a one-year postponement.

4. The confidentiality of data on individual companies precludes reference to the position of particular firms in the various credit markets. 
pooled loans as collateral, and removing the loans from the balance sheet. Securitized receivables jumped from $\$ 25$ billion (5 percent of total receivables) in 1990 to $\$ 126$ billion (16 percent of the total) in 1996. Although consumer receivables continued to represent more than half of total securitized receivables at mid-1996, securitized business receivables expanded more rapidly over the period.

\section{Business Receivables}

Decades ago, consumer loans formed the largest part of finance company assets, but business finance surpassed consumer finance in the mid-1970s, and has exceeded consumer finance each year since then. At \$341 billion, or 44 percent of total receivables, business receivables in 1996 were the largest part of finance company operations. But in terms of growth rate, business lending has fallen back; its 4.7 percent compounded annual growth rate over the 1990-96 period was about half that of total consumer receivables.

The financing of non-automotive capital equipment formed the largest and fastest growing of the three components of business finance, accounting for 60 percent of total business receivables in the 1996 survey, compared with about half in the 1990 survey (table 2). The other two components of business receivables at finance companies are motor vehicles and a miscellaneous category ("other") that includes the financing of accounts receivable and whose share dropped considerably from the earlier survey.

1. Major categories of finance company receivables outstanding, owned and securitized, by category, 1990 and 1996

\begin{tabular}{|c|c|c|c|c|c|c|}
\hline \multirow{2}{*}{ Category } & \multicolumn{2}{|c|}{$\begin{array}{l}\text { Billions } \\
\text { of dollars }\end{array}$} & \multicolumn{2}{|c|}{$\begin{array}{l}\text { Growth } \\
\text { (percent) }\end{array}$} & \multicolumn{2}{|c|}{$\begin{array}{l}\text { Share of total } \\
\text { (percent) }\end{array}$} \\
\hline & 1990 & 1996 & $\begin{array}{l}\text { Cumu- } \\
\text { lative }\end{array}$ & $\begin{array}{c}\text { Annual } \\
\text { rate }\end{array}$ & 1990 & 1996 \\
\hline Total & 505.3 & 771.4 & 52.7 & 7.3 & 100 & 100 \\
\hline Owned ... & 480.4 & 645.0 & 34.3 & 5.0 & 95.1 & 83.6 \\
\hline Securitized & 24.9 & 126.4 & 408.4 & 31.1 & 4.9 & 16.4 \\
\hline Business . & 258.9 & 341.3 & 31.8 & 4.7 & 51.2 & 44.2 \\
\hline Owned .... & 255.8 & 305.7 & 19.5 & 3.0 & 50.6 & 39.6 \\
\hline Securitized & 3.1 & 35.6 & $1,051.5$ & 50.3 & .6 & 4.6 \\
\hline Consumer & 185.2 & 326.3 & 76.2 & 9.9 & 36.7 & 42.3 \\
\hline Owned & 163.4 & 259.0 & 58.5 & 8.0 & 32.3 & 33.6 \\
\hline Securitized & 21.8 & 67.3 & 209.2 & 20.7 & 4.3 & 8.7 \\
\hline Real estate & 61.2 & 103.8 & 69.5 & 9.2 & 12.1 & 13.5 \\
\hline Owned .... & 61.2 & 80.4 & 31.2 & 4.6 & 12.1 & 10.4 \\
\hline Securitized & n.a. & 23.5 & n.a. & n.a. & n.a. & 3.0 \\
\hline Мемо & & & & & & \\
\hline Total net assets & 530.7 & 824.6 & 55.4 & 7.6 & & . \\
\hline
\end{tabular}

As business credit grew as a share of finance company activity in the 1980 s, finance companies increased their share of all short- and intermediateterm business credit, from about 19 percent in 1985 to 25 percent at the time of the 1990 survey (table 3). Numerous factors played a role in the shift in market shares between commercial banks and finance companies. Although the relative importance of each is not entirely clear, they likely included financial deregulation, which created a more competitive environment between bank and nonbank lenders; industry consolidation, which sharply reduced the number of commercial banks; risk-based capital regulations, which increased the capital required of large portions of the banking industry; and substantial loan losses, which led many banks initially to tighten the terms and standards for underwriting business loans and to strengthen their capital positions. ${ }^{5}$

The slowing in the growth of business receivables at finance companies during the current decade reflects a less rapid pace of short- and intermediateterm business borrowing in general, but also more gradual gains in market share by these firms. A factor that likely contributed to the latter development was the opportunity perceived by the industy for substantial profits in such consumer products as credit cards and "subprime" (higher risk) lending.

Ironically, another factor helping to slow the growth of business receivables at finance companies may have been the relatively favorable macroeconomic conditions over the second half of the 1990-96 period. The strengthening economy of 1992 and beyond likely boosted the demand for financial services by new and expanding small businesses, a segment of the economy to which commercial banks historically have been the major providers of credit and other financial services. Data from the 1993 National Survey of Small Business Finances (NSSBF) indicate that 41 percent of small businesses obtained credit lines, loans, and leases from depository lenders, including commercial banks and thrift institutions, but only 19 percent of these businesses turned to nondepository lenders, primarily finance

5. For a more complete discussion of factors affecting bank and nonbank competition, see Rebel A. Cole, John D. Wolken, and R. Louise Woodburn, "Bank and Nonbank Competition for Small Business Credit: Evidence from the 1987 and 1993 National Surveys of Small Business Finances," Federal Reserve Bulletin, vol. 82, November 1996, pp. 983-95, and other references contained therein. See also Mark Carey, Mitchell Post, and Steven A. Sharpe, "Does Corporate Lending by Banks and Finance Companies Differ? Evidence on Specialization in Private Debt Contracting," revision of Finance and Economics Discussion Series 96-25 (Board of Governors of the Federal Reserve System, January 1997). 
companies, for such credit products. ${ }^{6}$ Strengthening balance sheets of business firms since 1993 may have encouraged banks to ease lending standards for their business customers, and bank lending to businesses in general has rebounded strongly since 1993 (although the bank share declined over the 1990-96 period as a whole).

As is true for business lending in general, the level of business receivables at finance companies may be understated to some extent by business use of credit instruments treated in the statistics as consumer or real estate loans. Many small business owners rely on mortgages and personal credit cards to provide part of their overall financing needs. For example, 39 percent of the respondents to the 1993 NSSBF reported using a personal credit card for business purposes.

Finally, 1995 revisions to the Community Reinvestment Act of 1977 require larger depository institutions to disclose information about their small business lending, thereby sharpening the focus on such lending in the assessment of the performance of creditors covered by the act. ${ }^{7}$ These regulatory

6. The 1993 survey was cosponsored by the Federal Reserve Board and the U.S. Small Business Administration to collect information about the sources and types of financial services obtained by small businesses. See Rebel A. Cole and John D. Wolken, "Financial Services Used by Small Businesses: Evidence from the 1993 National Survey of Small Business Finances," Federal Reserve Bulletin, vol. 81, July 1995, pp. 629-67.

7. The act was intended to encourage depository institutions to meet the credit needs of households and small businesses in the communities where the institutions are chartered. For a description of the act and its evolution during the 1980s and 1990s, see Griffith L. Garwood and Dolores S. Smith, "The Community Reinvestment Act: Evolution and Current Issues," Federal Reserve Bulletin, vol. 79, April 1993, pp. 251-67. changes may have prompted some depository lenders to be more aggressive in seeking out opportunities for lending to small businesses.

\section{Equipment Finance}

Equipment finance maintained a relatively strong growth rate of 8 percent between benchmarks (table 2). Details are not collected on the specific types of capital goods covered by equipment finance, but computers, other office machines, airplanes, and construction equipment probably form the largest subcategories. Leasing has long been the most common form of equipment finance provided by these companies; in both the 1990 and 1996 surveys, about two-thirds of equipment receivables were leases.

\section{Motor Vehicle Finance}

Motor vehicle finance reached nearly $\$ 90$ billion in June 1996. The wholesale category consists mainly of inventory ("floor plan") financing for automobile and truck dealers, provided chiefly by the finance subsidiaries of the car and truck manufacturers. In the 1996 survey, finance companies had $\$ 32$ billion in wholesale motor vehicle receivables, about the same as in 1990. However, a notable change from the previous survey was the additional $\$ 22$ billion of securitized wholesale receivables. At the time of the 1990 survey, the practice of securitizing wholesale receivables had just been initiated, and the total of such instruments then amounted to only about $\$ 1$ billion. About one-fourth of all business motor vehicle credit is now funded by securitization.

2. Distribution of business receivables outstanding at finance companies, by category, 1990 and 1996

\begin{tabular}{|c|c|c|c|c|c|c|c|c|}
\hline \multirow{2}{*}{ Category } & \multicolumn{2}{|c|}{ Billions of dollars } & \multicolumn{2}{|c|}{ Growth (percent) } & \multicolumn{2}{|c|}{$\begin{array}{l}\text { Share of category } \\
\text { (percent) }\end{array}$} & \multicolumn{2}{|c|}{$\begin{array}{l}\text { Share of total } \\
\text { (percent) }\end{array}$} \\
\hline & 1990 & 1996 & Cumulative & $\begin{array}{l}\text { Annual } \\
\text { rate }\end{array}$ & 1990 & 1996 & 1990 & 1996 \\
\hline Total & 258.9 & 341.3 & 31.8 & 4.7 & 100 & 100 & 100 & 100 \\
\hline Equipment & 129.4 & 205.0 & 58.4 & 8.0 & 100 & 100 & 50.0 & 60.1 \\
\hline Loans .. & 40.0 & 58.2 & 45.5 & 6.4 & 30.9 & 28.4 & 15.5 & 17.1 \\
\hline Leases . & 89.4 & 137.9 & 54.2 & 7.5 & 69.1 & 67.3 & 34.5 & 40.4 \\
\hline Securitized & n.a. & 8.9 & n.a. & n.a. & n.a. & 4.4 & n.a. & 2.6 \\
\hline Motor vehicle & 67.1 & 89.3 & 33.0 & 4.9 & 100 & 100 & 25.9 & 26.2 \\
\hline \multicolumn{9}{|l|}{ Wholesale } \\
\hline Loans ...... & 32.9 & 32.3 & -1.8 & -0.3 & 49.0 & 36.2 & 12.7 & 9.5 \\
\hline Securitized & 1.0 & 22.2 & $2,143.8$ & 67.9 & 1.5 & 24.9 & .4 & 6.5 \\
\hline \multicolumn{9}{|l|}{ Retail } \\
\hline Loans & 29.2 & 25.0 & -14.1 & -2.5 & 43.4 & 28.0 & 11.3 & 7.3 \\
\hline Leases $\ldots . .$. & 2.0 & 7.8 & 291.4 & 25.5 & 3.0 & 8.7 & 8 & 2.3 \\
\hline Securitized & 2.1 & 1.9 & -7.6 & -1.3 & 3.1 & 2.2 & .8 & .6 \\
\hline Other ... & 62.4 & 47.1 & -24.5 & -4.6 & 100 & 100 & 24.1 & 13.8 \\
\hline Loans... & 62.4 & 44.6 & -28.5 & -5.4 & 100 & 94.7 & 24.1 & 13.1 \\
\hline Securitized & n.a. & 2.5 & n.a. & n.a. & n.a. & 5.3 & n.a. & .7 \\
\hline
\end{tabular}

Note. As of June 30 .

n.a. Not available. 
Retail finance of motor vehicles for business customers consists mainly of loans and leases to relatively small businesses operating small fleets of vehicles. (Larger companies typically obtain their funds for financing such capital expenditures from earnings and the direct issuance of debt in capital markets.) As of June 1996, finance companies had $\$ 25$ billion in retail vehicle loans to businesses and about $\$ 8$ billion in retail leases; an additional $\$ 2$ billion of retail loans and leases had been securitized.

\section{Other Business Receivables}

Little detail is available on the composition of "other" business receivables. It includes commercial accounts receivable, factored commercial accounts, floor-plan loans for dealers in non-automotive goods, and small cash loans to businesses or farms. ${ }^{8}$ The category declined over the period between benchmarks, dropping from $\$ 62$ billion in 1990 to $\$ 47$ billion in 1996.

\section{Consumer Receivables}

Consumer finance has been the fastest growing segment of finance company activities in the current decade, expanding at a 9.9 percent compound annual rate between the 1990 and 1996 surveys (table 4). Consumer receivables, including securitized loans and leases, reached $\$ 326$ billion at mid-year 1996, up from $\$ 185$ billion at mid-1990. On the strength of a three-fold increase in car and truck leasing, motor vehicle finance has been the main force behind the expansion of consumer receivables; it accounted for

8. "Other" business receivables refers to any loans or other types of credit (including equipment operating leases) a survey respondent reports after being queried about commercial vehicle loans, "floor plan" financing (financing of inventory of motor vehicle dealers), loans for business, industrial, and farm equipment, and most types of leasing. See appendix B for added detail on "other" business receivables. two-thirds of total consumer finance in the latest survey. Revolving credit (mainly credit card receivables) doubled during the period, but at $\$ 47$ billion still constituted a relatively small part of total consumer finance. "Other" consumer loans, composed of personal cash loans, sales finance contracts, and other, smaller pieces, lagged a bit in growth. The lag partly reflects the more widespread availability and use of credit cards, which have become more convenient substitutes for many types of consumer loans in the "other" category.

\section{Motor Vehicle Finance}

The "captive" subsidiaries of the motor vehicle manufacturers are by far the largest source of motor vehicle finance among finance companies. Through financial incentives and innovative products, the captives help their parent manufacturers smooth fluctuations in motor vehicle demand arising from changes in macroeconomic and financial market conditions. In this regard, they have played a key role since the mid-1980s in popularizing the motor vehicle lease as a consumer product.

In 1985, revisions to the federal tax code phased out the deductibility of interest payments on consumer loans and thus boosted the relative appeal to consumers of leases for financing the acquisition of automobiles, light trucks, and sport utility vehicles. In the latter part of the decade, automakers began offering highly attractive lease terms as a marketing tool through their finance company subsidiaries. They reduced monthly lease payments by calculating them with relatively low implicit interest rates and high residual values (the latter of which results in less depreciation to be financed by the lease payment); this approach is a marketing strategy comparable to that for sales earlier in the decade, in which they used below-market interest rates on loans and cash rebates to spur auto sales. Vigorous promotion of leasing was extended to the light truck segment in the early 1990s. As a result of these developments, consumer

3. Selected domestic sources of short- and intermediate-term business credit, selected years, 1980-96

\begin{tabular}{|c|c|c|c|c|c|c|c|c|}
\hline \multirow{2}{*}{ Source } & \multicolumn{4}{|c|}{ Outstanding (billions of dollars) } & \multicolumn{4}{|c|}{ Share of total (percent) } \\
\hline & 1980 & 1985 & 1990 & 1996 & 1980 & 1985 & 1990 & 1996 \\
\hline Total & 423.9 & 787.6 & $1,020.4$ & $1,215.5$ & 100 & 100 & 100 & 100 \\
\hline Commercial banks ....... & 297.3 & 568.6 & 619.3 & 676.9 & 70.1 & 72.2 & 60.7 & 55.7 \\
\hline Direct (commercial paper) & 40.5 & 71.7 & 142.2 & 197.3 & 9.6 & 9.1 & 13.9 & 16.2 \\
\hline Finance companies ....... & 86.1 & 147.3 & 258.9 & 341.3 & 20.3 & 18.7 & 25.4 & 28.1 \\
\hline
\end{tabular}

Note. As of June 30. 
motor vehicle leases outstanding at finance companies (including securitized leases) grew from an estimated $\$ 22$ billion in mid-1990 to a reported $\$ 94$ billion in mid-1996 (about 27 percent compound annual growth). ${ }^{9}$

The surge in lease receivables has reestablished finance companies as the largest supplier of motor vehicle financing to consumers, a position that commercial banks had held since the late 1950s. Total consumer automotive receivables rose from $\$ 118$ billion to $\$ 217$ billion at finance companies from 1990 to 1996, whereas at banks such receivables rose during the period from $\$ 132$ billion to only $\$ 160$ billion. ${ }^{10}$ Although the lion's share of such growth at finance companies was attributable to leasing, loans outstanding (both on book and securitized) expanded 28 percent, a $\$ 27$ billion increase that nearly matched the increase at banks over the sixyear period. Finance companies took advantage of continuing strong investor demand for asset-backed securities to securitize most of the loan growth, thereby restraining the growth of assets carried on their balance sheets and thus minimizing the need for direct financing. This move was probably instrumental in allowing the companies to maintain highly favorable debt ratings while significantly expanding their role as suppliers of motor vehicle finance.

9. The 1990 survey did not collect information on motor vehicle leases separately for consumers and businesses; only the total was reported. However, for comparison with results of the 1996 survey, individual consumer and business components were estimated using the distribution reported in 1996.

10. The bank data for these years do not include leases, but banks have not been very heavily involved in that form of consumer finance.

\section{Revolving Credit}

Revolving credit at finance companies consists almost entirely of balances outstanding on credit card accounts (revolving home equity loans are classified as real estate debt). These receivables, including a bit more than $\$ 6$ billion of securitized credit card debt, amounted to $\$ 47$ billion in the 1996 survey, double the level of outstandings in 1990. A substantial part of these receivables-about $\$ 18$ billion in mid1996 - are originated and carried at bank subsidiaries of large, diversified finance companies. However, in view of the more than $\$ 450$ billion of revolving credit balances outstanding at all lenders as of mid-1996, finance companies play a relatively small role in this sector of the consumer finance market.

\section{Other Consumer Receivables}

"Other" consumer receivables comprises a diverse mix of nonmortgage consumer loans, and they registered only slow growth over the 1990-96 period. Personal cash loans, once the preeminent loan product of non-automotive finance companies, is probably the largest component of "other." 11 Sales finance contracts-loans made to finance the purchase of specific items (such as furniture or appliances) and usually originated by retail stores and sold to finance

11. "Other" consumer receivables refers to loans and other types of credit that a survey respondent reported after being queried about loans to purchase motor vehicles, revolving lines of credit, and loans secured by real estate. Companies were not requested to report any detail for "other" consumer receivables; see definitions (appendix B) for more information on this category.

4. Distribution of consumer receivables at finance companies, by category, 1990 and 1996

\begin{tabular}{|c|c|c|c|c|c|c|c|c|}
\hline \multirow{2}{*}{ Category } & \multicolumn{2}{|c|}{$\begin{array}{l}\text { Outstanding } \\
\text { (billions of dollars) }\end{array}$} & \multicolumn{2}{|c|}{$\begin{array}{l}\text { Growth } \\
\text { (percent) }\end{array}$} & \multicolumn{2}{|c|}{$\begin{array}{l}\text { Share of category } \\
\text { (percent) }\end{array}$} & \multicolumn{2}{|c|}{$\begin{array}{l}\text { Share of total } \\
\text { (percent) }\end{array}$} \\
\hline & 1990 & 1996 & Cumulative & Annual rate & 1990 & 1996 & 1990 & 1996 \\
\hline Total & 185.2 & 326.3 & 76.2 & 9.9 & 100 & 100 & 100 & 100 \\
\hline Motor vehicle & 118.2 & 217.3 & 83.8 & 10.7 & 100 & 100 & 63.9 & 66.6 \\
\hline Loans ...... & 96.1 & 123.0 & 28.0 & 4.2 & 81.3 & 56.6 & 51.9 & 37.7 \\
\hline Owned .... & 79.8 & 86.3 & 8.1 & 1.3 & 67.5 & 39.7 & 43.1 & 26.4 \\
\hline Securitized & 16.2 & 36.7 & 125.7 & 14.5 & 13.7 & 16.9 & 8.7 & 11.2 \\
\hline Leases ........ & 22.2 & 94.3 & 325.4 & 27.3 & 18.7 & 43.4 & 11.9 & 28.9 \\
\hline Owned ........... & 22.2 & 86.7 & 291.3 & 25.5 & 18.7 & 39.9 & 11.9 & 26.6 \\
\hline Securitized & n.a. & 7.6 & n.a. & n.a. & n.a. & 3.5 & n.a. & 2.3 \\
\hline Revolving & 23.3 & 46.5 & 99.1 & 12.2 & 100 & 100 & 12.6 & 14.2 \\
\hline Loans & 22.5 & 40.1 & 78.7 & 10.2 & 96.2 & 86.4 & 12.1 & 12.3 \\
\hline Securitized & .9 & 6.3 & 621.5 & 39.0 & 3.8 & 13.6 & .5 & 1.9 \\
\hline Other ... & 43.6 & 62.5 & 43.3 & 6.2 & 100 & 100 & 23.6 & 19.2 \\
\hline Loans .... & 39.0 & 45.8 & 17.4 & 2.7 & 89.4 & 73.2 & 21.1 & 14.0 \\
\hline Securitized & 4.6 & 16.7 & 260.9 & 23.9 & 10.6 & 26.8 & 2.5 & 5.1 \\
\hline
\end{tabular}


companies-are also a sizable element of this category. The importance of sales finance contracts and cash loans has dwindled over the years as banks have steadily moved toward the riskier end of the creditrisk spectrum in their marketing of credit cards and as a number of the large finance companies have established credit card operations of their own. Mobile home loans also are classified as "other" consumer receivables and constitute the collateral behind most of the securitized receivables labeled "other."

\section{Real Estate Receivables}

With $\$ 104$ billion in real estate receivables under management in mid-1996 (table 1), finance companies inhabit only a small corner of the $\$ 5$ trillion market for residential and commercial mortgage credit. Nevertheless, real estate lending has grown vigorously at finance companies in recent years; receivables increased at a 9.2 percent compound annual rate between the 1990 and 1996 surveys. ${ }^{12}$

The latest survey elicited more detail than did the preceding surveys concerning types of real estate loans outstanding. Loans to individual homeowners on one- to four-family properties make up the largest element of real estate lending, consisting in 1996 of $\$ 47$ billion in loans on book and another $\$ 23$ billion securitized. Commercial mortgages, including those on farm and multifamily properties, amounted to $\$ 33$ billion.

Nearly all of the $\$ 71$ billion in loans to individuals represents home equity loans rather than loans to purchase homes. Most commonly, the home equity loans held by finance companies are closed-end with fixed interest rates, but some companies also issue home equity lines of credit, usually with adjustable interest rates (separate figures on open- and closedend loans were not collected). Banks have the largest presence in the home equity loan market; for June 1996, banks reported $\$ 146$ billion of open- and closed-end home equity loans on their books. Figures for lenders other than banks and finance companies are less precisely measured, but home equity credit in total is estimated to have been about $\$ 320$ billion in mid-1996; finance companies were thus serving about one-fifth of that segment of the mortgage market.

12. The quinqennial survey does not collect information on the lending activities of mortgage banking companies. These specialized home mortgage lenders function primarily as mortgage originators, financing their lending activities almost entirely through securitization and generally carrying loans on their balance sheets pending future securitization.

\section{Industry Concentration}

Like surveys in previous years, the 1996 survey revealed further concentration among finance companies. For the twenty largest firms ranked by total net assets, total receivables as a share of total industry receivables increased a bit, from 69 percent in 1990 to 71 percent in 1996 (table). Among the major categories of receivables, only business receivables became less concentrated among the twenty largest firms, but by only 4 percentage points.

The concentration of consumer receivables and real estate receivables jumped during the intrasurvey period, about 8 and 10 percentage points respectively. However, the largest increase in concentration came in securitized receivables, which rose 13 percentage points, to 55 percent. As noted, the growth in both business and consumer motor vehicle loans was financed in large part by increased securitization. Larger, more well-established securitization programs are likely to provide the greatest cost benefits for their sponsoring companies because the market yields on their securities generally require the smallest risk premiums.

Proportion of finance company receivables, by category, held at twenty largest firms, 1990 and 1996

\begin{tabular}{|c|c|c|c|c|c|c|}
\hline \multirow{3}{*}{ Category } & \multirow{2}{*}{\multicolumn{2}{|c|}{$\begin{array}{l}\text { Outstanding } \\
\text { receivables } \\
\text { at all finance } \\
\text { companies } \\
\text { (billions } \\
\text { of dollars) }\end{array}$}} & \multicolumn{4}{|c|}{$\begin{array}{c}\text { Outstanding receivables at } \\
\text { twenty largest finance companies }{ }^{1}\end{array}$} \\
\hline & & & \multicolumn{2}{|c|}{$\begin{array}{l}\text { Amount } \\
\text { (billions } \\
\text { of dollars) }\end{array}$} & \multicolumn{2}{|c|}{$\begin{array}{l}\text { Share of all } \\
\text { finance } \\
\text { companies } \\
\text { (percent) }\end{array}$} \\
\hline & 1990 & 1996 & 1990 & 1996 & 1990 & 1996 \\
\hline Total & 505.3 & 771.4 & 346.9 & 547.2 & 68.6 & 70.9 \\
\hline Business & 277.9 & 305.7 & 186.7 & 194.5 & 67.2 & 63.6 \\
\hline Consumer & 141.3 & 259.0 & 109.6 & 221.9 & 77.6 & 85.7 \\
\hline Real estate & 61.2 & 80.4 & 40.1 & 61.1 & 65.5 & 76.0 \\
\hline Securitized & 24.9 & 126.4 & 10.4 & 69.8 & 41.8 & 55.2 \\
\hline $\begin{array}{l}\text { MEMo } \\
\text { Total net assets ... }\end{array}$ & 530.7 & 824.6 & 379.6 & 638.3 & 71.5 & 77.4 \\
\hline
\end{tabular}

Although home equity loans extended by a finance company typically rank below the top tier in credit quality, interest rates for these collateralized loans still tend to be lower than most credit card rates. Moreover, home equity loans also feature longer repayment periods than credit card debt. Thus finance companies have marketed home equity loans, in part, as a means of consolidating credit card debt because doing so can reduce the borrower's monthly payments substantially. Moreover, interest paid on a home equity loan is a tax-deductible expense, providing an additional attraction for those who can itemize such expenses on their tax returns. 
Home equity lending at finance companies has grown markedly in the past three years or so, after a period of sluggish growth in the overall market for such credit. In the early part of the current decade, stagnant or declining home values in many areas and the recession's overall damping effect on consumer spending and borrowing deterred households from taking on much additional home equity debt; moreover, when interest rates fell to twenty-year lows in 1993, many homeowners liquidated outstanding home equity loans in the course of refinancing all their mortgage debt into one first-lien mortgage. ${ }^{13}$ By 1995, home values were advancing moderately, the economy was stronger, and the wave of refinancing had ebbed: Households were once again using home equity to collateralize debt. Home equity loans from all sources increased an estimated 11 percent in 1995 and 17 percent last year, to a year-end total of about $\$ 350$ billion. Growth at finance companies apparently exceeded these aggregate increases in both years. ${ }^{14}$

Finance companies appear to have increased their presence in home equity lending even more rapidly following the 1996 survey, funneling much of this debt into securitized pools. ${ }^{15}$ Part of the recent growth represents an attempt by finance companies to compete for business going to the highly profitable credit card segment of consumer lending, which is dominated by banks; to do so, the finance companies have expanded their use of subprime home equity loans as a logical extension of their traditional business of lending to individuals on a largely unsecured basis.

13. For a more complete discussion of the factors that limited borrowing against home equity in the early 1990s, see Glenn B. Canner, Thomas A. Durkin, and Charles A. Luckett, "Home Equity Lending: Evidence from Recent Surveys," Federal Reserve Bulletin, vol. 80, July 1994, pp. 571-83.

14. Precise estimates of growth in home equity lending at finance companies cannot be made for 1995 and 1996. As noted, the statistics on real estate credit at finance companies were not disaggregated into home mortgage and commercial components until the June 1996 survey, nor were comprehensive data on real estate securitizations at these companies compiled until that time. Over the second half of 1996, the home mortgage component expanded at a 31 percent annual rate.

15. The types of loans characterized by the "home equity" label have expanded significantly in recent years. In the 1980s, the defining characteristic of these loans was their status as second lien real estate loans. They were used primarily for debt consolidation or home improvement and also were characterized by relatively low balances, shorter maturities, and low overall loan-to-value ratios when combined with other mortgage debt of the borrower. In addition, most borrowers were considered A-quality credits.

More recently, home equity loans have come to be defined primarily by their status as nonconforming loans-including subprime loans - owing either to their more flexible underwriting standards or to the lower overall credit quality of the borrower. Thus, home equity loans currently include first or junior lien loans that have fixed or adjustable rates, that have relatively high loan-to-value ratios, and that are used for home purchase, debt consolidation, or refinancing.
Subprime loans include those with more lenient underwriting standards (such as high loan-to-value ratios), those made to borrowers with blemished credit histories, and those with both characteristics. One such product introduced in just the past year is the so-called one-twenty-five home equity loan, in which the creditor will lend an amount that raises the homeowner's total mortgage debt to 125 percent of the home's estimated market value (a condition that effectively places at least part of the mortgage outside the coverage of the collateral).

To assess the level of credit risk associated with subprime lending, finance companies and other lenders have come to rely increasingly on credit scoring models as well as on more traditional methods of evaluating credit risk. Credit scoring techniques have been used by many lenders to increase underwriting efficiency and reduce loss rates. These models use statistical techniques to estimate the probability of default on the basis of a variety of loan and borrower characteristics. ${ }^{16}$

\section{SOURCES OF FINANCING AT FINANCE COMPANIES}

Finance companies traditionally have operated on a relatively narrow base of equity. That base remained remarkably stable at around 11 percent of total liabilities and capital over the 1990-96 period (table 5). In addition, borrowings from parent companies as a share of total liabilities and capital also remained unchanged at about 7 percent over the period.

The most striking change in the industry's major sources of financing since 1990 was the fairly sharp decline in its reliance on commercial paper. Its use of bank loans also slipped. The decline was more than offset by increases in other borrowings in capital markets - debt not elsewhere classified (NEC) — and in miscellaneous categories of borrowing.

In part, the shift in industry financing from commercial paper and bank loans to debt NEC and miscellaneous debt likely reflected a pickup among the highly rated companies in the use of medium-term notes. The use of this type of financing increased sharply over the 1990-96 period, especially since 1992, as many companies used their medium-term note programs to lock in relatively low financing costs for periods longer than those typically available

16. For a more complete discussion of credit scoring models, see Robert B. Avery, Raphael W. Bostic, Paul S. Calem, and Glenn B. Canner, "Credit Risk, Credit Scoring, and the Performance of Home Mortgages,' Federal Reserve Bulletin, vol. 82, July 1996, pp. 622-48. 
5. Finance company liabilities and capital, 1990 and 1996

\begin{tabular}{|c|c|c|c|c|c|c|}
\hline \multirow{2}{*}{ Item } & \multicolumn{2}{|c|}{ Outstanding (billions of dollars) } & \multicolumn{2}{|c|}{ Growth (percent) } & \multicolumn{2}{|c|}{ Share of total (percent) } \\
\hline & 1990 & 1996 & Cumulative & Annual rate & 1990 & 1996 \\
\hline Bank loans ........ & 31.5 & 17.7 & -43.8 & -9.2 & 5.9 & 2.1 \\
\hline Commercial paper & 164.0 & 169.6 & 3.4 & .6 & 30.9 & 20.6 \\
\hline Debt due to parent $\ldots \ldots \ldots .$. & 36.6 & 57.1 & 56.1 & 7.7 & 6.9 & 6.9 \\
\hline Debt not elsewhere classified & 171.7 & 323.7 & 88.5 & 11.1 & 32.3 & 39.3 \\
\hline Other $\ldots \ldots \ldots \ldots \ldots \ldots \ldots$ & 64.9 & 165.5 & 155.2 & 16.9 & 12.2 & 20.1 \\
\hline Total liabilities & 468.6 & 733.6 & 56.5 & 7.8 & 88.3 & 89.0 \\
\hline Capital, surplus, and undivided profits & 62.1 & 91.0 & 46.4 & 6.6 & 11.7 & 11.0 \\
\hline Total & 530.7 & 824.6 & 55.4 & 7.6 & 100 & 100 \\
\hline
\end{tabular}

Note. As of June 30 .

in the commercial paper market. For example, a Federal Reserve survey found that medium-term notes outstanding at finance companies, excluding the auto finance companies, doubled from $\$ 39$ billion at the end of 1992 to $\$ 78$ billion at the end of $1996 .{ }^{17}$

As discussed above, finance companies have made extensive use of securitization in recent years as a means to fund the financial services they provide to the business and household sectors. The standard accounting practice is to treat the securitized receivables and the related securities as off-balance-sheet items; viewed functionally, however, securitization is best understood as a means of financing lending operations that is closely akin to the issuance of collateralized company debt.

Securitization was supporting $13^{1 / 4}$ percent of the industry's total (balance sheet plus securitized) operations as of mid-1996, compared with $41 / 2$ percent at mid-1990. The proportions of total funding obtained through traditional on-balance-sheet sources were reduced accordingly. For instance, in the June 1996 survey, commercial paper was funding 173/4 percent of total finance company activities, compared with $291 / 2$ percent in the June 1990 survey.

\section{DEVELOPMENTS SINCE THE JUNE 1996 BENCHMARK}

In the nine months between June 30,1996, and the end of March 1997, the growth of finance company receivables slowed marginally, as a surge in home equity lending only partly offset a cooling of consumer and business finance (table 6). The growth rate of the business receivables component slackened only

17. See Michael P. O’Malley and Joyce A. Payne, "1996 Survey of Corporate Medium-Term Notes," Board of Governors of the Federal Reserve System, April 1997. moderately, but the composition of business credit growth changed considerably. Equipment financeby far the strongest component between the surveys - contracted slightly, and "other" business credit reversed a long-term decline by growing at a 13 percent rate.

Consumer receivables at finance companies grew at a substantially slower pace in the 1996-97 period than they did in the preceding six years, a decline that was in line with the trend in consumer borrowing generally. Each component of consumer receivables slowed to some extent in the latest period, particularly motor vehicle finance. Leasing continued to grow rapidly but the amount of motor vehicle loans outstanding was somewhat below its June 1996 level.

Real estate finance has expanded rapidly since the middle of last year because of hefty gains in the volume of home equity lending, as discussed above.

6. Major categories of finance company receivables, 1990, 1996, and March 1997

\begin{tabular}{c|r|r|r|r|r}
\hline \multirow{2}{*}{ Category } & \multicolumn{3}{|c|}{$\begin{array}{c}\text { Outstanding } \\
\text { (billions of dollars) }\end{array}$} & \multicolumn{2}{c}{$\begin{array}{c}\text { Annual growth rate } \\
\text { (percent) }\end{array}$} \\
\cline { 2 - 6 } & 1990 & 1996 & $\begin{array}{c}\text { March 31, } \\
1997\end{array}$ & $1990-96$ & $1996-971$ \\
\hline Total ........... & $\mathbf{5 0 5 . 3}$ & $\mathbf{7 7 1 . 4}$ & $\mathbf{8 0 0 . 7}$ & $\mathbf{7 . 3}$ & $\mathbf{5 . 1}$ \\
Business ......... & 258.9 & 341.3 & 348.4 & 4.7 & 2.8 \\
Equipment ..... & 129.4 & 205.0 & 202.4 & 8.0 & -1.7 \\
Motor vehicle .. & 67.1 & 89.3 & 94.3 & 4.9 & 7.5 \\
Other ......... & 62.4 & 47.1 & 51.7 & -4.6 & 13.0 \\
Consumer ........ & 185.2 & 326.3 & 336.8 & 9.9 & 4.3 \\
Motor vehicle ... & 118.2 & 217.3 & 224.2 & 10.7 & 4.2 \\
Revolving ....... & 23.3 & 46.5 & 49.6 & 12.2 & 8.9 \\
Other ......... & 43.6 & 62.5 & 63.0 & 6.2 & 1.1 \\
Real estate ....... & 61.2 & 103.8 & 115.5 & 9.2 & 15.0 \\
Households .... & n.a. & 70.7 & 85.1 & n.a. & 27.2 \\
Commercial .... & n.a. & 33.1 & 30.4 & n.a. & -10.9 \\
\hline
\end{tabular}

Note. Includes leases and securitized receivables as well as loans on company balance sheets. Data for 1990 and 1996 are as of June 30.

1. Annualized percentage change from June 30, 1996, to March 31, 1997 (not seasonally adjusted).

n.a. Not available. 
Loans to households grew at a 27 percent rate from mid-1996 through March, but the overall gain in real estate receivables was held to a 15 percent rate by a decline in commercial real estate loans. Much of the new volume was securitized: Finance company mortgages in asset pools increased at a 50 percent annual rate.

As suggested by the developments in real estate finance, securitization continued to find favor with finance companies as a means to fund the growth of receivables. In addition to their making sizable increases in the amount of home equity loans they pooled as backing for securities, finance companies also securitized substantial amounts of credit card receivables and non-automotive consumer loans. Across all major categories of finance, securitized receivables grew at an $81 \frac{1}{2}$ percent annual rate in the nine months through March 1997, while loans on book increased about one-half that rate.

\section{APPENDIX A: SAMPLING PROCEDURES}

Pre-survey questionnaires were mailed to 3,017 companies (the population-frame mailing list) that were identified from the 1990 survey mailing list, the Equipment Leasing Association of America, the American Financial Services Association, and various publications. Responses to the pre-survey questionnaire, as well as responses from follow-up surveys, determined the sampling frame. Data were collected on the size of the company, its primary type of activity or specialty, and the classification of its parent, if any. Companies were deleted from the mailing list if they responded to the questionnaire with information that showed they were out of business, were sold to another firm, were not a finance company, or were a subsidiary of another finance company (table A.1).

\section{A.1. Responses to finance company survey, by disposition} of forms, 1996

\begin{tabular}{|c|c|c|}
\hline Disposition & Number & Percent \\
\hline Total mailed & 3,017 & 100 \\
\hline Returned & 2,209 & 73.2 \\
\hline Usable & 859 & 28.5 \\
\hline Not usable .... & 1,350 & 44.7 \\
\hline Postal return & 836 & 27.7 \\
\hline Not a finance company & 93 & 3.1 \\
\hline Out of business ........ & 231 & 7.6 \\
\hline Finance company & & \\
\hline subsidiary & 120 & 4.0 \\
\hline Bank subsidiary & 55 & 1.8 \\
\hline Other $\ldots \ldots \ldots$ & 15 & .5 \\
\hline Not returned & 808 & 26.8 \\
\hline
\end{tabular}

Follow-up surveys of both the nonrespondents and the postal returns were taken to improve the sampling frame and estimate additional companies that belong in the population. With telephone follow-up methods to expedite the data collection and improve the results, a stratified random sample of 184 nonrespondents yielded 60 usable companies. This outcome allowed the addition of 263 companies to the population in the same proportion as existed in the sample regarding size and specialty class.

In a like manner, a stratified random sample of 120 postal returns yielded 16 usable companies. Applying frequency rates to the usable postal returns by size and specialty added an estimated 115 companies to the population. Combining these estimates with the number of usable companies from the presurvey mailing, the total number of finance companies in the population on June 30, 1996, was estimated at 1,237.

The June 30, 1996, benchmark survey consisted of two sample groups of companies: the 74 finance companies surveyed monthly for the Domestic Finance Company Report (FR 2248) and a stratified random sample of 526 additional companies from the population-frame mailing list. All of the 74 monthly reporters responded. A total of 157 of the 526 sampled companies responded, producing an effective sample size of 231 companies. Despite the low overall sample response rate of 38 percent, large companies are well represented. Data were collected from 58 of the 63 companies with assets greater than $\$ 1$ billion. These 63 companies are estimated to hold about 95 percent of the total net assets of the industry.

Population estimates of assets and liabilities were produced using the stratified mean expansion estimator. Strata were based on the size and specialty of the company. The estimator is defined as

$$
Y=\Sigma Y(h)=\sum \frac{N(h) * y(h)}{n(h)}
$$

where

$$
\begin{aligned}
N(h)= & \text { total number of companies in stratum } h \\
n(h)= & \text { number of sample companies in stratum } h \\
y(h)= & \text { sample aggregate total for companies in } \\
& \text { stratum } h \\
Y(h)= & \text { estimated aggregate total for stratum } h \\
Y= & \text { estimated national total. }
\end{aligned}
$$


A.2. Assets and liabilities outstanding at finance companies, by size of company, June 30, 1996 Millions of dollars

\begin{tabular}{|c|c|c|c|c|c|c|c|}
\hline \multirow[b]{2}{*}{ Item } & \multirow[b]{2}{*}{ All } & \multicolumn{6}{|c|}{ Size of company (net assets, millions of dollars) } \\
\hline & & $\begin{array}{c}5,000 \\
\text { and more }\end{array}$ & $1,000-4,999$ & 200-999 & 50-199 & $10-49$ & Less than 10 \\
\hline \multicolumn{8}{|l|}{ Assets } \\
\hline Consumer receivables .... & 258,961 & 234,441 & 14,566 & 4,230 & 3,009 & 1,494 & 1,221 \\
\hline Motor vehicle financing & 173,062 & 160,380 & 5,822 & 4,013 & 1,828 & 463 & 557 \\
\hline Loans ................. & 86,333 & 76,712 & 2,764 & 4,013 & 1,824 & 463 & 557 \\
\hline Leases .................. & 86,729 & 83,668 & 3,058 & 0 & 3 & 0 & 0 \\
\hline Capital and leveraged & 20,736 & 17,679 & 3,058 & 0 & 0 & 0 & 0 \\
\hline Operating ............. & 65,993 & 65,990 & 0 & 0 & 3 & 0 & 0 \\
\hline Revolving credit & 40,132 & 38,034 & 1,983 & 0 & 1 & 99 & 15 \\
\hline Other ............ & 45,767 & 36,027 & 6,761 & 216 & 1,180 & 933 & 649 \\
\hline Loans secured by real estate & 80,353 & 68,101 & 10,020 & 1,245 & 419 & 371 & 197 \\
\hline One-to-four family homes & 47,258 & 38,526 & 8,086 & & 217 & 257 & 165 \\
\hline Commercial and farm ..... & 33,095 & 29,575 & 1,934 & 1,238 & 203 & 113 & 32 \\
\hline Business receivables ...... & 305,722 & 225,528 & 54,752 & 17,501 & 5,430 & 1.544 & 967 \\
\hline Motor vehicle financing & 65,098 & $\begin{array}{r}58,829 \\
\end{array}$ & 5,080 & 374 & 614 & 59 & 142 \\
\hline Wholesale ............ & 32,294 & 31,387 & 785 & 102 & 0 & 0 & 20 \\
\hline Retail .... & 32,804 & 27,442 & 4,295 & 272 & 614 & 59 & 122 \\
\hline Loans . & 25,034 & 21,904 & 2,786 & 0 & 193 & 29 & 122 \\
\hline Leases .................... & 7,770 & 5,538 & 1,509 & 272 & 421 & 30 & 0 \\
\hline Capital and leveraged & 5,879 & 4,005 & 1,340 & 147 & 362 & 26 & 0 \\
\hline Operating ............. & 1,891 & 1,534 & 169 & 125 & 59 & 4 & 0 \\
\hline \multicolumn{8}{|l|}{ Business, industrial, and farm } \\
\hline equipment $\ldots \ldots \ldots \ldots \ldots$ & 161,872 & 113,569 & 33,659 & 11,086 & 2,502 & 834 & 221 \\
\hline Loans (retail and wholesale). & 58,169 & 45,151 & 9,413 & 2,960 & 170 & 326 & 148 \\
\hline Leases (capital and leveraged) & 103,703 & 68,418 & 24,246 & 8,127 & 2,332 & 507 & 73 \\
\hline Other $\ldots \ldots \ldots \ldots$ & 44,602 & 23,797 & 13,858 & 5,172 & 703 & 467 & 604 \\
\hline Non-motor vehicle operating leases & 34,149 & 29,332 & 2,155 & 868 & 1,610 & 184 & 0 \\
\hline All other assets and receivables & 251,521 & 230,266 & 10,453 & 7,636 & 1,978 & 633 & 556 \\
\hline Total assets, gross $\ldots \ldots \ldots \ldots \ldots$ & 896,557 & 758,336 & 89,792 & 30,611 & 10,836 & 4.042 & 2.941 \\
\hline Less reserves for unearned income & 58,874 & 46,150 & 8,806 & 2,236 & 980 & 347 & 355 \\
\hline Less reserves for losses .......... & 13,106 & 9,998 & 1,612 & 912 & 356 & 166 & 63 \\
\hline Total assets, net & 824,576 & 702,188 & 79,373 & 27,462 & 9,500 & 3,529 & 2,523 \\
\hline \multicolumn{8}{|l|}{ Liabilities AND CAPITAL } \\
\hline Bank loans $\ldots \ldots \ldots \ldots \ldots \ldots$ & 17,690 & 4,914 & 6,502 & 2,532 & 2,109 & 928 & 705 \\
\hline Commercial paper & 169,568 & 152,210 & 12,484 & 4,324 & 440 & 35 & 75 \\
\hline Debt due to parent $\ldots \ldots \ldots . .$. & 57,121 & 25,071 & 23,438 & 6,622 & 1,605 & 339 & 47 \\
\hline Debt not elsewhere classified & 323,673 & 300,490 & 16,637 & 3,581 & 1,710 & 588 & 668 \\
\hline All other liabilities .................... & 165,538 & 146,252 & 10,039 & 6,940 & 1,414 & 601 & 293 \\
\hline Capital, surplus, and undivided profits & 90,985 & 73,252 & 10,272 & 3,464 & 2,222 & 1,038 & 736 \\
\hline Total liabilities and capital & 824,576 & 702,188 & 79,373 & 27,462 & $\mathbf{9 , 5 0 0}$ & 3,529 & 2,523 \\
\hline \multicolumn{8}{|l|}{ МЕмо } \\
\hline \multicolumn{8}{|l|}{ Securitized Receivables } \\
\hline Consumer receivables $\ldots \ldots \ldots \ldots$ & 67,304 & 62,373 & 479 & 3,751 & 655 & 44 & 0 \\
\hline Motor vehicle financing & 44,241 & 39,865 & 107 & 3,751 & 518 & 0 & 0 \\
\hline Loans ........................ & 36,675 & 32,298 & 107 & 3,751 & 518 & 0 & 0 \\
\hline Leases (capital and leveraged) & 7,566 & 7,566 & 0 & 0 & 0 & 0 & 0 \\
\hline Revolving credit $\ldots \ldots \ldots \ldots \ldots$ & 6,320 & 6,276 & 0 & 0 & 0 & 44 & 0 \\
\hline Other consumer receivables & 16,742 & 16,233 & 372 & 0 & 137 & 0 & 0 \\
\hline Loans secured by real estate & 23,455 & 21,074 & 2,380 & 0 & 0 & 0 & 0 \\
\hline One-to-four family ........ & 23,445 & 21,074 & 2,371 & 0 & 0 & 0 & 0 \\
\hline Commercial and farm & 10 & 0 & 10 & 0 & 0 & 0 & 0 \\
\hline Business receivables ...... & 35,594 & 26,960 & 7,175 & 1,257 & 69 & 115 & 17 \\
\hline Motor vehicle financing & 24,155 & 21,510 & 2,592 & 12 & 37 & 4 & 0 \\
\hline Wholesale ............. & 22,214 & 21,339 & 875 & 0 & 0 & 0 & 0 \\
\hline Retail .... & 1,941 & 171 & 1,717 & 12 & 37 & 4 & 0 \\
\hline Loans & 1,888 & 171 & 1,717 & 0 & 0 & 0 & 0 \\
\hline Leases .................... & $\begin{array}{r}1,000 \\
53\end{array}$ & 0 & 0 & 12 & 37 & 4 & 0 \\
\hline Capital and leveraged & 12 & 0 & 0 & 12 & 0 & 0 & 0 \\
\hline Operating ............. & 41 & 0 & 0 & 0 & 37 & 4 & 0 \\
\hline \multicolumn{8}{|l|}{ Business, industrial, and farm } \\
\hline equipment ................ & 8,944 & 4,468 & 3,630 & 702 & 33 & 111 & 0 \\
\hline Loans (retail and wholesale) & 4,864 & 1,234 & 3,630 & 0 & 0 & 0 & 0 \\
\hline Leases (capital and leveraged) & 4,081 & 3,234 & 0 & 702 & 33 & 111 & 0 \\
\hline Other $\ldots \ldots \ldots \ldots \ldots$ & 2,495 & 983 & 953 & 543 & 0 & 0 & 17 \\
\hline Total securitized receivables & 126,352 & 110,408 & 10,034 & 5,009 & 725 & 160 & 17 \\
\hline \multicolumn{8}{|l|}{ Number of companies responding } \\
\hline to survey $\ldots \ldots \ldots \ldots \ldots$ & 231 & 30 & 28 & 23 & 32 & 41 & 77 \\
\hline $\begin{array}{l}\text { Estimated number of companies } \\
\text { in population } \ldots \ldots \ldots \ldots \ldots . . .\end{array}$ & 1,237 & 30 & 33 & 54 & 87 & 138 & 895 \\
\hline
\end{tabular}

Note. See definitions in appendix B. 


\section{APPENDIX B: DEFINITIONS OF CATEGORIES}

For purposes of this survey, a finance company is defined as a company (including Morris Plan companies but excluding banks, credit unions, savings and loan associations, cooperative banks, and savings banks) in which the largest portion of the company's assets is in one or more of the following kinds of receivables:

- Sales finance receivables. Installment paper arising from retail sales of passenger cars and mobile homes, other consumer goods, such as general merchandise, apparel, furniture, and household appliances, or from outlays for home improvement loans not secured by real estate.

- Personal cash loans to individuals and families. Unsecured cash loans (including loans to pay for insurance policies) or cash loans secured by insurance policies, autos already paid for, and other collateral.

- Short- and intermediate-term business receivables. Loans on commercial accounts receivables, inventory loans, factoring, lease financing, retail installment sales (or purchases) of commercial, industrial, and farm equipment and commercial vehicles, and wholesale financing of consumer and business goods.

- Real estate loans. Loans, whatever the purpose, secured by real property (as evidenced by deeds of trust, land contracts, or other instruments) and including junior-lien home-equity loans or second mortgages.

\section{Asset Items}

Receivables include direct loans and loans purchased from manufacturers and retailers before deduction of reserves for unearned income and reserves for losses.

\section{Consumer Receivables}

A. Motor Vehicle Financing. Credit arising from retail sales of passenger cars and other vehicles such as vans and pickup trucks. It excludes fleet sales, personal cash loans secured by automobiles already paid for, loans to finance the purchase of commercial vehicles and farm equipment, and lease financing.

B. Revolving Credit. Retail credit that is extended on a credit-line basis and that arises from the sale of consumer goods other than passenger cars and mobile homes. A single contract governs multiple use of the account and purchases may be made with a credit card. Generally, credit extensions can be made at the consumer's discretion, provided that they do not cause the outstanding balance of the account to exceed a prearranged credit limit.

C. Other Consumer Receivables. All credit arising from retail sales of consumer goods other than passenger cars that is not extended under a revolving credit line. Includes financing of general merchandise, apparel, furniture, household appliances; campers, trailers, mobile homes (when classified by state law as personal property), motorcycles, airplanes, helicopters, and boats purchased for personal use; loans for automobile repair; credit to finance alterations or improvements in existing residential properties occupied by the borrower; secured and unsecured loans made directly to the borrower for household, family, or other personal expenses; and unsecured loans to purchase auto insurance policies as well as loans secured by insurance policies, automobiles already paid for, and other collateral. It excludes loans for business purposes, rediscounted loans, loans secured by real estate, and wholesale and lease financing.

\section{Loans Secured by Real Estate}

A. One- to Four-Family. Credit arising from revolving or permanent loans secured by real estate as evidenced by mortgages (FHA, FmHA, VA, or conventional) or other liens (first or junior) on nonfarm property containing one to four dwelling units (including vacation homes) or more than four dwelling units if each is separated from other units by dividing walls that extend from ground to roof (row houses, townhouses, or the like); mobile homes when state laws define the purchase or holding of a mobile home as the purchase or holding of real property and where the loan to purchase the mobile home is secured by that mobile home as evidenced by a mortgage or other instrument on real property; individual condominium dwelling units and loans secured by an interest in individual cooperative units, even if in a building with five or more dwelling units; vacant lots in established single-family residential sections or in areas set aside primarily for one- to four-family homes; and housekeeping dwellings with commercial units combined where use is primarily residential and where only one- to four-family dwelling units are involved. 
B. Multifamily. Credit arising from permanent nonfarm residential loans secured by real estate as evidenced by mortgages (FHA or conventional) or other liens on nonfarm properties with five or more dwelling units in structures (including apartment buildings and apartment hotels) used primarily to accommodate households on a more or less permanent basis; housekeeping dwellings of five or more units with commercial units combined where use is primarily residential; cooperative-type apartment buildings containing five or more dwelling units; and vacant lots in established multifamily residential sections or in areas set aside primarily for multifamily residential properties.

C. Commercial and Farm. Credit arising from loans secured by real estate as evidenced by mortgages or other liens on business and industrial properties, hotels, motels, churches, hospitals, educational and charitable institutions, dormitories, clubs, lodges, association buildings, care facilities for aged persons and orphans, golf courses, recreational facilities, and similar properties. It includes all other nonresidential loans secured by real estate as evidenced by mortgages or other liens. Credit arising from loans secured by farmland and improvements thereon, as evidenced by mortgages or other liens. Farmland includes all land known to be used or usable for agricultural purposes, such as crop and livestock production, grazing or pasture land, whether tillable or not, and whether wooded or not.

\section{Business Receivables}

A. Motor Vehicle Financing. Consists of retail credits and wholesale credits.

(1) Retail (commercial vehicles). Credit arising from retail sales of commercial land vehicles to business. It includes trucks, buses, taxicabs, truck trailers, and other on-the-road vehicles for which motor vehicle licensing is required. It also includes fleet sales of passenger cars, but excludes lease financing and paper on business, industrial, or farm equipment.

(2) Wholesale. Credit arising from transactions between manufacturers and dealers or other floorplan loans secured by passenger cars and commercial land vehicles. It excludes paper secured by mobile homes, passenger car trailers, boats, airplanes, helicopters, and business, industrial, and farm equipment.

B. Business, Industrial, and Farm Equipment. Consists of retail and wholesale credits and capital and leveraged leases.
(1) Retail and wholesale financing. Credit arising from the retail sale to business of (or for the purchase of) business, industrial, and farm equipment. It includes all off-the-road equipment for which motor vehicle licensing is not required as well as airplanes, helicopters, and boats purchased for business use. Loans may be secured by chattel mortgages or conditional sales contracts (purchased money security agreements) on the machinery or equipment. It excludes loans to purchase commercial land vehicles for which motor vehicle licensing is required and loans secured by real estate. It also excludes lease financing. Wholesale financing is credit arising from transactions between manufacturers and dealers or other floor-plan loans secured by business, industrial, and farm equipment. It includes all off-the-road equipment for which motor vehicle licensing is not required, such as airplanes, helicopters, and boats.

(2) Capital and leveraged leases. Lease receivables arising from the leasing of business, industrial, and farm equipment. It includes lease financing of all off-the-road equipment for which motor vehicle licensing is not required and lease financing of airplanes, helicopters, and boats leased for business use. It excludes lease financing of airplanes, helicopters, and boats leased for personal or family use (included in asset item 3.C), and excludes operating leases as defined by Financial Accounting Standards Board Statement of Financial Accounting Standards 13 (SFAS 13).

C. Other Business Receivables (Excluding Operating Leases). All other wholesale financing not reported in asset items 3.A.2 and 3.B.1 above, including floor-plan transactions between manufacturers and dealers for items such as mobile homes, campers, and travel trailers. Includes all other business capital and leveraged lease receivables not reported in asset items 3.B.2 above and not reported in asset items 4.A.2, below, including credit arising from the leasing of mobile homes, campers, and travel trailers. Excludes operating leases as defined by SFAS 13 that are included in asset items 4.B and 5 below. Includes business credit with original maturities of up to five years, including loans secured by commercial accounts receivable less the balances withheld for customers pending collection of receivables; commercial accounts receivable purchased from factored clients less any amount due and payable to factored clients; and secured and unsecured advances of funds to factored clients. It includes dealer loans, capital loans, small loans used primarily for business or farm purposes, multicollateral loans, rediscounted receivables of other finance companies less balances with- 
held, and all other business loans not elsewhere classified. It excludes loans secured by real estate (unless included as part of a multicollateral loan) which is included in asset items 2 .

\section{Motor Vehicle Leases}

Lease receivables arising from leasing of passenger cars and commercial land vehicles, but excluding leasing of mobile homes, campers, motor trailers, boats, airplanes, helicopters, and business, industrial, and farm equipment.

A. Capital and Leveraged Leases. Consists of consumer and business leases.

(1) Consumer. Refer to credit on types of receivables covered by asset items 1.A above.

(2) Business. Refer to credit on types of receivables covered by asset items 3.A.1 above.

B. Operating Leases (as defined by SFAS 13). Consists of consumer and business leases.

(1) Consumer. Refer to credit on types of receivables covered by asset items 1.A above.

(2) Business. Refer to credit on types of receivables covered by asset items 3.A.1 above.

\section{Non-Motor Vehicle Operating Leases}

For business, industrial, and farm equipment, refer to credit on types of receivables covered by asset items 3.B.1 above. For all other equipment, refer to credit on types of receivables covered by asset items 1.C and 3.C above. It includes all operating leases as defined by SFAS 13 that are excluded from the asset items above.

A. Consumer. Refer to credit on types of receivables covered by asset items 1.C above.

B. Business. Refer to credit on types of receivables covered by asset items 3.B.1 and 3.C above.

\section{All Other Assets and Accounts and Notes Receivable}

All assets not already included above, including consolidated companies' investments in nonconsolidated foreign and domestic subsidiaries and affiliates. Nonconsolidated subsidiary and affiliate company claims on consolidated companies (except debt due to par- ent) should be netted against the consolidated companies' investment. It excludes operating leases reported as asset items 4.B and 5 above and excludes overdrafts.

\section{Reserves}

A. Reserves for Unearned Income. Includes unearned discounts and service charges on the above receivables.

B. Reserves for Losses. Allowances for bad debts, unallocated charge-offs, and any other valuation allowances except the amount of unearned income applicable to the receivables included above.

\section{Total Assets, Net}

Sum of asset items 1.A through 6 minus asset items 7.A and 7.B.

\section{Securitized Asset Items}

Securitized assets include receivables that have been packaged and sold by the reporting finance company to a trustee or other third party who uses the receivables package as collateral for an asset-backed security that is sold to investors. These assets are no longer on the balance sheet of the reporting finance company and thus are not included in the asset items. Securitized assets consist of the total amount outstanding, including all receivables securitized in the current month and in prior months. They include assets such as leases that were never on the company books, but whose securitizations may be counted as a managed asset, and exclude the amounts of outright asset sales that have not been packaged to collateralize an asset-backed security. Securitized assets are reported using the same definitions used for their unsecuritized counterparts in asset items 1 through 5 above.

\section{Liabilities and Capital Items}

\section{Bank Loans}

Short- and long-term loans and notes payable to banks. Includes overdrafts but excludes commercial paper and bank portions of participation loans. 


\section{Commercial Paper}

Promissory notes of large denominations sold directly or through dealers to investors and issued for not longer than 270 days. It includes short-term or demand "master" notes and paper backed by letters of credit or other guarantees, but excludes nonnegotiable promissory notes held by officers of the firm, their families, and other individuals (which are included in liabilities and capital item 4).

\section{Debt Due to Parent}

For a company that is the subsidiary of another company (which is not a finance company), it includes all short- and long-term indebtedness owed to the parent company, but excludes the parent company's equity (which is included in liabilities and capital item 6).

\section{Debt Not Elsewhere Classified}

All other short- and long-term loans, notes, certificates, negotiable paper, or other indebtedness not elsewhere classified. It excludes bank debt already included in liabilities and capital items 1 and 3.

\section{All Other Liabilities}

All liabilities not already reported above or netted against assets. It includes dealer reserves, all tax accruals, short-term certificates of thrift or investment, deposit liabilities (other than those not withdrawable during term of loan), and all other liabilities. It excludes liabilities of consolidated companies to nonconsolidated subsidiaries of affiliated companies, which should be netted against assets in asset items 6 or shown in liabilities and capital items 3. It also excludes borrower repayment deposits accumulated but not credited against indebtedness until repayment is made in full, which should be netted against appropriate receivables under asset items above.

\section{Capital, Surplus, and Undivided Profits}

All common and preferred stock and other capital or surplus accounts, including undivided profits.

\section{Total Liabilities and Capital}

Sum of liabilities and capital items 1 through 6. 